\title{
Synthesis and Bacterial Evaluation of The V(IV), Cr(III), Fe(III) and Co(II) Ions Complexes with Mixed Ligands (2-hydroxybenzaldine)-4- Aminoantipyrine and 8-Hydroxyquinoline
}

\author{
Israa H. Ibraheem, Mahasin F. Alias and Doaa U. Ali* \\ Department of Chemistry, College of Science for Women, University of Baghdad. \\ *Environment and Water Directorate, Minstery of Science and Technology, Baghdad-Iraq.
}

\begin{abstract}
The primary ligand (2-hydroxybenzaldine)-4-aminoantipyrine (L)was prepared as achelating ligand, Which was treated with V(IV), Cr(III), Fe(III) and $\mathrm{Co}(\mathrm{II})$ ions in alcoholic medium in order to prepare series of new metal complexes in the presence of the Co-ligand 8-hydroxyquinoline.

These complexes were prepared by convential method and characterized by available techniques, FT-IR, UV-Visible, magnetic susceptibility, flame atomic absorption technique as well as elemental analysis and conductivity measurements. From these studiesmeasurements, asquare pyramidal structure proposed for V(IV) while octahedral geometry for $\mathrm{Cr}(\mathrm{III}), \mathrm{Fe}(\mathrm{III})$ and $\mathrm{Co}(\mathrm{II})$ complexes. Thebacterial activity of the prepared complexes have been determine and compared with the ligands.
\end{abstract}

Keywords: Mixed ligands, 4-aminoantipyrine, 8-hydroxyquinolin, antibacterialactivity, transition elements.

\section{Introduction}

The coordination compounds display a large diversity offered by the great variety of metal centers and ligand shapes [1]. In modern coordination compounds almost all organic and inorganic compounds can be used as ligands, then the design and synthesis of coordination compound have attracted much attention from chemists [2]. The cyclic systems containing carbon atoms and at least one other element are called heterocyclic such as furan, pyrrol, oxazol, thazole, thiazole, pyrazole, pyrrolidine [3] andother the heterocyclic compounds benzothiazoles are widely distributed in nature and essential to life in various ways [4-6].

8-hydroxyquinolin (oxine) behaves as bidenatethrough ( $\mathrm{N}$ and $\mathrm{O}$ ) as a univalent ligand to form chelates with several metal ions [7]. Compounds containing quinoline moiety are great interest to synthetic and medicinal chemists due to their unique chemical and biological properties [8].

Oxine is abicyclic aromatic and is toxic if injected [9]. However its derivatives have long been used for their antibacterial and antifungal activity $[10,11]$ another applications of quinoline complexes, the quinoline ligands effectivily sensitize neodymium ions emission following photo-excitation of polymer host [12] and also used as the electron transport light emitting layer in such organic light emitting diodes [13].

\section{Experimental}

\section{1- Chemicals and Instrumentation}

Chemicals which used are $\operatorname{VOSO}_{4} \cdot \mathrm{H}_{2} \mathrm{O}$, $\mathrm{Cr}\left(\mathrm{NO}_{3}\right)_{3} .6 \mathrm{H}_{2} \mathrm{O}, \quad \mathrm{Fe}\left(\mathrm{NO}_{3}\right)_{3} .9 \mathrm{H}_{2} \mathrm{O}, \quad \mathrm{Co}\left(\mathrm{NO}_{3}\right)_{2}$. $6 \mathrm{H}_{2} \mathrm{O}, 1-10$-phenanthroline, Ethanol absolute salicldehyde, 4-aminoantipyrineand glacial acetic acid equipped from different companies FLUKA and BDH with high purity. The FT-IR for ligand and their metal complexes were recorded in therange $4000-200 \mathrm{~cm}^{-1}$ as a (CsI) disc on IR-Prestige-21, Single Beam Path Laser Shimadzu Infrard Spectrophotometer (FT-IR) -8300. UV- Visible spectra were measured by using UV-1650 PC Shimadzu in the range $1100-200 \mathrm{~nm}$. The magnaticsusceptibility values of the prepared complexes were estimated at room temperature using Balance Magnetic Suceptibility Model MSB- MKT, the conductivity measurements of the prepared complexes were obtained using $0.001 \mathrm{M}$ in absolute ethanol solvent, $\mathrm{Pw}$-Digital Meter of Conductivity. Elemental C.H.N analysis were carried out on a EM-101.mth instrument at Al-Bayt University. Atomic absorption measurements of the prepared complexes were obtained using Shimadzu Atomic Absorption 680 Flame Spectrophotometer. The melting 
point of ligands and prepared complexes measured by using Stuart Melting Point Apparatus.

\section{2- Preperation of 2-hydroxybenzaldine-4- aminoantipyrine (L)}

Acoording to the literature [14], the ligand 2-hydroxybenzaldine-4-aminoantipyrine was prepared as in the following scheme (1).<smiles>Cc1c(N)c(=O)n(-c2ccccc2)n1C</smiles>

4-aminoantipyrine<smiles>O=Cc1ccccc1O</smiles>

salicyaldehyde<smiles>Cc1c(N=Cc2ccccc2O)c(=O)n(-c2ccc(O)cc2)n1C</smiles>

L

Scheme (1): The rout of preparation 2-hydreoxybenzaldine-4- aminoantipyrine $(L)$.

\section{3- Preperation metal complexes}

(0.3 g, 1 mmole) of free Schiff base (L) was dissolved in absolute ethanol solvent and then added $\left(\mathrm{L}^{-}\right)(0.14 \mathrm{~g}, 1 \mathrm{mmole})$ which dissolved in same a solvent. To the mixture added $(1 \mathrm{mmole})$ of metal salts $\left[\left(0.1 \mathrm{~g} \mathrm{VOSO}_{4} \cdot \mathrm{H}_{2} \mathrm{O}\right)\right.$, $\left(0.28 \mathrm{~g} \quad \mathrm{Cr} \quad\left(\mathrm{NO}_{3}\right)_{3} .6 \mathrm{H}_{2} \mathrm{O}\right), \quad(0.34 \mathrm{~g}$ $\left.\mathrm{Fe}\left(\mathrm{NO}_{3}\right)_{3} .9 \mathrm{H}_{2} \mathrm{O}\right)$ and $\left.\left(0.29 \mathrm{~g} \mathrm{Co}\left(\mathrm{NO}_{3}\right)_{2} .6 \mathrm{H}_{2} \mathrm{O}\right)\right]$ were mixed in 1:1:1 ( $\left.\mathrm{M}: \mathrm{L}: \mathrm{L}^{-}\right)$. The resulting solution was refluxed for about (2-4) hrs. The colored precipitated was filtered and the recrystallized with ethanol and drying in oven $50{ }^{\circ} \mathrm{C}$, some physical properties and analytical data are tabulated in Table (1).

\section{4- Bactericial activity}

Bactericidal activity of the ligands and their complexes were evaluated against representative gram-positive and gramnegative bacteria by agar-plate method [15]. All the prepared compounds as drugs were prepared freshly by dissolving them in ethanol to obtain a final concentration of $1000 \mu \mathrm{g} / \mathrm{ml}$. All bacteria were cultivated in nutrient agar, the results are found in table (4).

\section{Result and Discussion}

\section{A- Chemistery}

The elemental analysis and atomic absorption shows 1:1: 1 (M: L: $\left.\mathrm{L}^{-}\right)$ stoichiometry for the prepared complexes. The analytical data together with some physical properties of the complexes are summarized in Table (1). The molar conductance values of the complexes inducating that the complexes are ionic for chromium and iron while cobalt and vanadium complexesarenon ionic. 
Table (1)

Show some physical properties and analytical data for prepared compounds.

\begin{tabular}{|c|c|c|c|c|c|c|c|c|}
\hline \multirow[t]{2}{*}{ Comp. } & \multirow{2}{*}{$\begin{array}{l}\text { M.W } \\
\text { g.mol }{ }^{-1}\end{array}$} & \multirow[t]{2}{*}{ colour } & \multirow[t]{2}{*}{ M.P.C } & \multirow{2}{*}{$\underset{\%}{\text { Yield }}$} & \multicolumn{3}{|c|}{$\begin{array}{l}\text { Elemental analysis } \\
\text { Found(Calc.) }\end{array}$} & \multirow{2}{*}{$\begin{array}{l}\text { Metal \% } \\
\text { Found } \\
\text { (Calc.) }\end{array}$} \\
\hline & & & & & $\mathrm{C \%}$ & Н \% & N \% & \\
\hline $\mathrm{L}$ & 307 & yellow & $239-241$ & 72 & $\begin{array}{l}70.65 \\
(70.34)\end{array}$ & $\begin{array}{c}3.65 \\
(3.90)\end{array}$ & $\begin{array}{l}12.92 \\
(13.86)\end{array}$ & - \\
\hline $\mathrm{L}^{-}$ & 145 & colorless & $81-83$ & - & - & - & - & - \\
\hline $\mathrm{VL} \mathrm{L}^{-}$ & 526 & light olive & $170 \mathrm{~d}$ & 81 & $\begin{array}{c}60.82 \\
(61.29)\end{array}$ & $\begin{array}{c}4.44 \\
(5.32)\end{array}$ & $\begin{array}{c}9.72 \\
(10.64)\end{array}$ & $\begin{array}{l}(8.88) \\
(9.67)\end{array}$ \\
\hline $\mathrm{CrL} \mathrm{L}^{-}$ & 609 & green & $217 \mathrm{~d}$. & 78 & $\begin{array}{c}54.13 \\
(53.20) \\
\end{array}$ & $\begin{array}{c}4.53 \\
(4.59) \\
\end{array}$ & $\begin{array}{c}12.47 \\
(11.49) \\
\end{array}$ & $\begin{array}{c}8.23 \\
(8.52) \\
\end{array}$ \\
\hline $\mathrm{FeL} \mathrm{L}^{-}$ & 631 & rednish brown & $220 \mathrm{~d}$. & 61 & $\begin{array}{c}51.68 \\
(51.34) \\
\end{array}$ & $\begin{array}{c}4.51 \\
(4.43) \\
\end{array}$ & $\begin{array}{c}10.84 \\
(10.09) \\
\end{array}$ & $\begin{array}{c}8.03 \\
(8.84) \\
\end{array}$ \\
\hline CoL L' & 581 & light brown & 129-131 & 72 & $\begin{array}{c}54.81 \\
(55.76)\end{array}$ & $\begin{array}{c}5.70 \\
(5.16)\end{array}$ & $\begin{array}{c}9.92 \\
(9.63)\end{array}$ & $\begin{array}{c}9.57 \\
(10.13)\end{array}$ \\
\hline
\end{tabular}

\section{FT-IR Study:}

FT-IR spectra for the ligand (L) [(2hydroxybenzaldine)-4-aminoantipyrine] and Co- ligand $\mathrm{L}^{-}(8$-hydroxyquinoline) show bands at $\left(3240 \mathrm{~cm}^{-1}\right)$ and $\left(3182 \mathrm{~cm}^{-1}\right)$ which attributed to stretching frequency of $v(\mathrm{OH})$ phenolic group for $(\mathrm{L})$ and $\left(\mathrm{L}^{-}\right)$respectively [16].

The medium bands which appeared at $1593 \mathrm{~cm}^{-1}$ and $1577 \mathrm{~cm}^{-1}$ both in ligands were assignable to strecting frequency of azomethane group $(\mathrm{C}=\mathrm{N})$ as in the litruture [17].

In the free Schiff base ligand (L) present band at $1654 \mathrm{~cm}^{-1}$ may be refer to the carbonyl group $(\mathrm{C}=\mathrm{O})[18]$ and slightly chang about $5 \mathrm{~cm}$ ${ }^{-1}$ when formation Vanadium, Chromium, Iron and Cobalt complexes, this result indicated their is noparcipitation of carbonyl group with all metal ions.

The deprotonation of phenol proton from free Schiff base and Co- ligand indicated the coordination of oxygen atom of phenolic group with the central metal atom [18]. The bands which appeared at $1269 \mathrm{~cm}^{-1}$ and $1224 \mathrm{~cm}^{-1}$ belonged to $v(\mathrm{C}-\mathrm{O})$ in the free Schiff base ligand and Co-ligand respectively, these bands were schifted to lower frequency around $(1210-1220) \mathrm{cm}^{-1}$ for all complexes, this schifted confirming the coordination of the oxygen atom of phenol group to the metal ions [20].

The bands azomethine group in both ligands where shifted to lower frequency when complexes formation. In the rang (1500-
1558) $\mathrm{cm}^{-1}$, this can be indicated the coordination of the nitrogen of imine moiety to the all metal ions [21]. New weak bands which appeared in the complexes in the rang (526-597) $\mathrm{cm}^{-1}$ and (425-450) $\mathrm{cm}^{-1}$ due to the stretching frequency of (M-N) and (M-O) bands respectively. The bands due to the ionic nitrate group which appeard almost in therang (1384-1022) $\mathrm{cm}^{-1}$ with some higher or lower frequencies comparable to this rang in some complexes, A broad bands observed around (3400-3440) $\mathrm{cm}^{-1}$ in the spectra of metal complexes, assigned to thev $(\mathrm{OH})$ which refer to presence of water molecules. The most diagnostic bands are summarized in the Table (2). 
Table (2)

The most characterstic bands of the compounds $\left(\mathrm{cm}^{-1}\right)$.

\begin{tabular}{|c|c|c|c|c|c|c|c|c|}
\hline Compound & $v(\mathrm{OH})$ Water & $\begin{array}{l}v(\mathrm{OH}) \\
\text { Phenol }\end{array}$ & $v(C=N)$ & $v(C=O)$ & $v(C-O)$ & $v(M-N)$ & v(M-O) & Other bands \\
\hline $\bar{L}$ & - & 3240 & 1593 & 1654 & 1269 & - & - & - \\
\hline$\overline{\mathbf{L}}$ & - & 3182 & 1577 & - & 1224 & - & - & - \\
\hline V L L & 3450 & 3062 & 1558 & 1650 & 1210 & 597 & 450 & $\begin{array}{l}\mathrm{V}=\mathrm{O}=970 \\
\mathrm{H}_{2} \mathrm{O}=3430\end{array}$ \\
\hline Cr L L & 3361 & 3062 & 1500 & 1655 & 1210 & 576 & 425 & $\begin{array}{c}\mathrm{H}_{2} \mathrm{O}=3400-3420 \\
\delta \mathrm{OH}=875 \\
\mathrm{NO}_{3}=1384,1031,1467 \\
\end{array}$ \\
\hline Fe LL' & 3390 & 3057 & 1551 & 1651 & 1220 & 526 & 455 & $\begin{array}{c}\mathrm{H}_{2} \mathrm{O}=3400-3440 \\
\delta \mathrm{OH}=877 \\
\mathrm{NO}_{3}=1380,1022,1458 \\
\end{array}$ \\
\hline CoLL' & 3406 & 3051 & 1551 & 1654 & 1220 & 540 & 432 & $\begin{array}{c}\mathrm{H}_{2} \mathrm{O}=3440-3410 \\
\delta \mathrm{OH}=865\end{array}$ \\
\hline
\end{tabular}

\section{Electronic Spectrum:-}

Most of transition complexes are colored and their colors are different, then this is an important indication of coordination between ligands and metal ions, therefore the colored complexes showed different characteristic absorption bands in their positions and intensity [22].

The electronic spectrum of ligand (L) shows a bsorption band in the ultraviolet region, the main band at $345 \mathrm{~nm}\left(28589 \mathrm{~cm}^{-1}\right)$ which assignable to the $\left(\mathrm{n} \rightarrow \pi^{*}\right)$ transition of imine group $(\mathrm{C}=\mathrm{N})$ [23]. The electronic spectrum of ligand $\left(\mathrm{L}^{-}\right) 8$ - hydroxyguinoline exhibits a very strong absorption band in ultraviolet region at $319 \mathrm{~nm}\left(31347 \mathrm{~cm}^{-1}\right)$ due to the $\left(\pi \rightarrow \pi^{*}\right)$ transition for the intera ligand aromatic system $(\mathrm{C}=\mathrm{C})$ [23].

\section{Vanadium (IV) complex:-}

The magnetic moment for the olive color $\mathrm{VO}$ (II) complex found to be $2.18 \mathrm{BM}$. at room temperature this value is higher than spin value of the vanadium ion only this result indicates a higher orbital contribution [24]. The diffuse reflectance spectrum of $\mathrm{VO}$ (II) complex displays three bands at 11037, 17241 and $21231 \mathrm{~cm}^{-1}$ which may be assigned to the ${ }^{2} \mathrm{~B}_{2} \rightarrow{ }^{2} \mathrm{E}(\mathrm{dxy} \rightarrow \mathrm{dxz}-\mathrm{dyz}),{ }^{2} \mathrm{~B}_{2} \rightarrow{ }^{2} \mathrm{~B}_{1} \quad\left(\mathrm{dxy} \rightarrow \mathrm{dx}^{2}-\mathrm{y}^{2}\right)$ and $\quad{ }^{2} \mathrm{~B}_{2} \rightarrow{ }^{2} \mathrm{~A}_{1} \quad\left(\mathrm{dxy} \rightarrow \mathrm{dz}^{2}\right) \quad$ transitions respectively, and other band at $30487 \mathrm{~cm}^{-1}$ which assignable to charge trancfer C.T, when measured the conductivity for the complex it is found non ionic, These transitions and the magnetic moment value came in accordance with the published data for square pyramidal geometry around $\mathrm{VO}(\mathrm{II})$ ion with a mononuclear structure [24].

\section{Chromium (III) complex:-}

The green color for the chromium (III) complex spectrum exhibites three bands at 1818, 23923 and $38461 \mathrm{~cm}^{-1}$ due to ${ }^{4} \mathrm{~A}_{2} \mathrm{~g} \rightarrow{ }^{4} \mathrm{~T}_{2} \mathrm{~g}, \quad{ }^{4} \mathrm{~A}_{2} \mathrm{~g} \rightarrow{ }^{4} \mathrm{~T}_{1} \mathrm{~g}$ and ${ }^{4} \mathrm{~A}_{2} \mathrm{~g} \rightarrow{ }^{4} \mathrm{~T}_{1} \mathrm{~g}(\mathrm{p})$ transitions respectively, with charge transfer which are assigned to spin allowed transition specific for $\mathrm{Cr}(\mathrm{III})$ in distorted octahedral symmetry[25]. All ligand filed parameters was calculated $\mathrm{B}^{\prime}, \mathrm{Dq}, 10 \mathrm{Dq}$ and $B$ using orgeldigram for $\mathrm{d}^{3}$ system as illustrated in Table (3), the magnetic moment value is 3.3 BM., and this complex is ionic when conductivity measured. Thus the octahedral structure has been suggested for this complex

\section{Ferric complex:-}

The spectrum of reddnish brown color of iron (III) complex shows (10309, 20618 and 27322) $\mathrm{cm}^{-1}$ which corresponding to ${ }^{6} \mathrm{~A}_{1} \mathrm{~g} \rightarrow{ }^{4} \mathrm{~T}_{1} \mathrm{~g},{ }^{6} \mathrm{~A}_{1} \mathrm{~g} \rightarrow{ }^{4} \mathrm{~T}_{2} \mathrm{~g}(\mathrm{G})$ and ${ }^{6} \mathrm{~A}_{1} \mathrm{~g} \rightarrow{ }^{4} \mathrm{~A}_{1} \mathrm{~g}+$ ${ }^{4} \mathrm{Eg}_{(\mathrm{G})}$ transition respectively and charge transfer at $31646 \mathrm{~cm}^{-1}$ [26]. The ligand filed parameter was estimated as in Table (3), The magnetic moment $\mu$ eff value for $\mathrm{Fe}$ (III) complex is $5.12 \mathrm{BM}$ indicating high spin for this complex. The complex is ionic, Electronic transition together with magnetic moment value suggested high spin octahedral geometry for ion complex. 


\section{Cobalte (II) complex:-}

In the spectrum of brown $\mathrm{Co}(\mathrm{II})$ complex, exhibite two bands at 1088 and $18315 \mathrm{~cm}^{-1}$ are associated to the transition ${ }^{4} \mathrm{~T}_{1} \mathrm{~g} \rightarrow{ }^{4} \mathrm{~T}_{2} \mathrm{~g}$ and ${ }^{4} \mathrm{~T}_{1} \mathrm{~g} \rightarrow{ }^{4} \mathrm{~T}_{1} \mathrm{~g}_{(\mathrm{P})}$ [27] respectively, and charge transfer at $30769 \mathrm{~cm}^{-1}$ these transitions are specified to the $\mathrm{Co}$ (II) ion in the field of octahedral symmetry, this complex is non ionic and the magnetic moment of $4.77 \mathrm{BM}$ corresponds to this high spin geometry. The $\mathrm{V}_{2}$, and $\mathrm{Dq}, \mathrm{B}^{\prime}, 10 \mathrm{Dq}$ and $\mathrm{B}$ was calculated using T.S.D for $\mathrm{d}^{7}$ system and this complex is non ionic nature. From these results, the disterted Oh structure was proposed for this complex.

Table (3)

Electronic spectral data of $L, L^{-}$and metal complexes and all ligand filedparameters, magnetic moment (BM) and conductance $\left(\mu \mathrm{scm}^{-1}\right)$.

\begin{tabular}{|c|c|c|c|c|c|c|c|c|c|c|c|}
\hline Comp. & $\begin{array}{c}\begin{array}{c}\text { Absorption } \\
\text { cm }^{-1}\end{array} \\
\end{array}$ & Assignment & Dq & $10 \mathrm{Dq}$ & B & $\mathbf{B}^{0}$ & B' & $15 B^{\prime}$ & $\mu_{\text {eff. }}$ & $\begin{array}{c}\text { Molar } \\
\text { Conductivity } \\
\end{array}$ & $\begin{array}{l}\text { Suggested } \\
\text { Structure }\end{array}$ \\
\hline \multirow[t]{2}{*}{$\mathbf{L}$} & 28589 & $\mathrm{n} \rightarrow \pi^{*}$ & & & & & & & & & \\
\hline & & & & & & & & & & & \\
\hline \multirow[t]{2}{*}{$\overline{\mathbf{L}^{\prime}}$} & 31347 & $\pi \rightarrow \pi^{*}$ & & & & & & & & & \\
\hline & & & & & & & & & & & \\
\hline \multirow[t]{4}{*}{ VL L' $\mathbf{L}^{-}$} & 11037 & $\mathrm{~B}_{2} \rightarrow{ }^{2} \mathrm{E}^{2}$ & & & & & & & & & \\
\hline & 17241 & ${ }^{2} \mathrm{~B}_{2} \rightarrow{ }^{2} \mathrm{~B}_{1}$ & & & & & & & & & \\
\hline & 21231 & ${ }^{2} \mathrm{~B}_{2} \rightarrow{ }^{2} \mathrm{~A}_{1}$ & & & & & & & 2.18 & 27 & Sq.Py \\
\hline & 30487 & $\begin{array}{l}\text { C.T } \\
\end{array}$ & & & & & & & & & \\
\hline \multirow[t]{3}{*}{ Cr L L ${ }^{-}$} & 18181 & ${ }^{4} \mathrm{~A}_{2} \mathrm{~g} \rightarrow{ }^{4} \mathrm{~T}_{2} \mathrm{~g}$ & 1728 & 17280 & 0.8 & 918 & 735 & 7841 & 3.3 & 40 & /distorded $\mathrm{Oh}$ \\
\hline & 23923 & ${ }^{4} \mathrm{~A}_{2} \mathrm{~g} \rightarrow{ }^{4} \mathrm{~T}_{1} \mathrm{~g}$ & & & & & & & & & \\
\hline & 38461 & ${ }^{4} \mathrm{~A}_{2} \mathrm{~g} \rightarrow{ }^{4} \mathrm{~T}_{1} \mathrm{~g}_{\mathrm{p}}$ & & & & & & & & & \\
\hline \multirow[t]{4}{*}{ Fe L L ${ }^{-}$} & 10309 & ${ }^{{ }^{6} \mathrm{~A}_{1} \mathrm{~g} \rightarrow{ }^{4} \mathrm{~T}_{1} \mathrm{~g}_{(\mathrm{G})}}$ & 1272 & 1212720 & 0.62 & 1300 & 848 & 17013 & 5.12 & 41 & /distorded $\mathrm{Oh}$ \\
\hline & 20618 & ${ }^{6} \mathrm{~A}_{1} \mathrm{~g} \rightarrow{ }^{4} \mathrm{~T}_{2} \mathrm{~g}_{(\mathrm{G})}$ & & & & & & & & & \\
\hline & 27322 & ${ }^{6} \mathrm{~A}_{1} \mathrm{~g} \rightarrow{ }^{4} \mathrm{~A}_{1} \mathrm{~g}+{ }^{4} \mathrm{Eg}_{(\mathrm{G})}$ & & & & & & & & & \\
\hline & 31646 & $\begin{array}{l}\text { C.T } \\
\end{array}$ & & & & & & & & & \\
\hline \multirow[t]{4}{*}{ Co $\mathrm{LL}^{-}$} & $\begin{array}{ll}10881 \\
\end{array}$ & ${ }^{{ }^{4} \mathrm{~T}_{1} \mathrm{~g} \rightarrow{ }^{4} \mathrm{~T}_{2} \mathrm{~g}}$ & 1053 & 10530 & 0.8 & 1030 & 780 & $\begin{array}{ll}11700 \\
\end{array}$ & 4.77 & 29 & $\begin{array}{ll}\text { distorded } \mathrm{Oh} \\
\end{array}$ \\
\hline & $26028 \mathrm{Cal}$. & ${ }^{4} \mathrm{~T}_{1} \mathrm{~g} \rightarrow{ }^{4} \mathrm{~A}_{2} \mathrm{~g}$ & & & & & & & & & \\
\hline & 18315 & ${ }^{4} \mathrm{~T}_{1} \mathrm{~g} \rightarrow{ }^{4} \mathrm{~T}_{2} \mathrm{~g}_{(\mathrm{p})}$ & & & & & & & & & \\
\hline & 30769 & C.T & & & & & & & & & \\
\hline
\end{tabular}

According to these results in addition to spectroscopic and analytical data, the following structures can be suggested in Fig. (1).<smiles>[R]N=C(C)COc1cccc2cccnc12</smiles><smiles>CC1C(=O)N(C)C1C</smiles> 


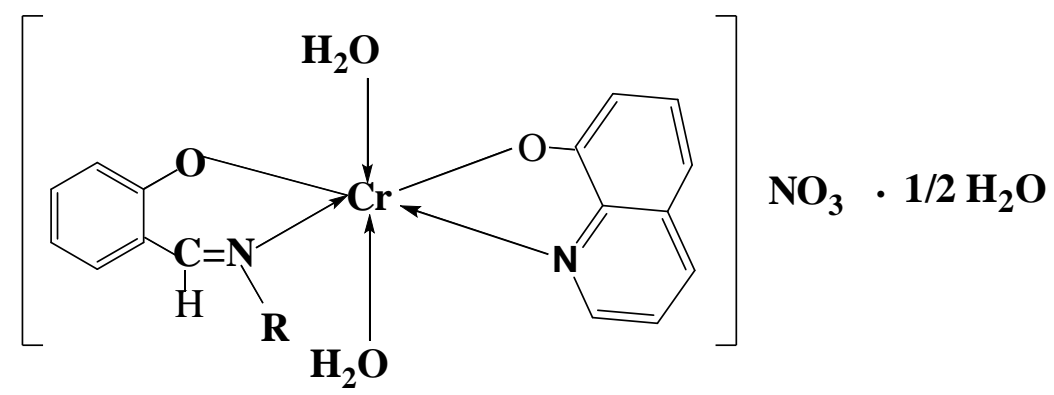<smiles>[Y7]c1c(C)c(=O)n(-c2ccccc2)n1C</smiles>

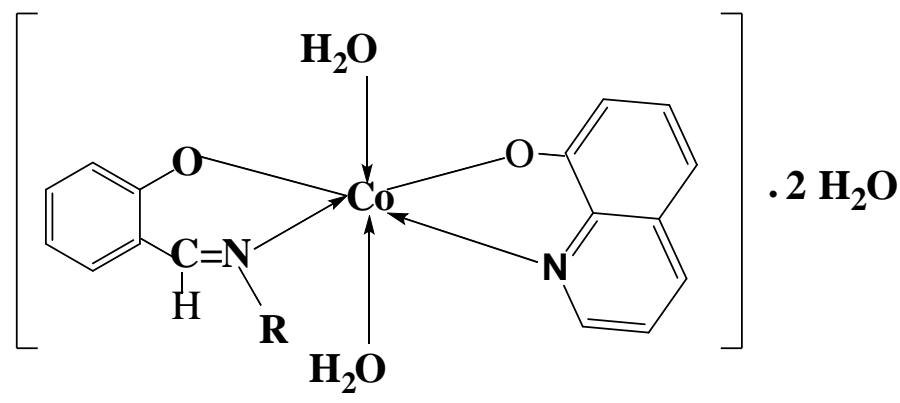<smiles>[R7]C1=C(C)[C@H](C)N(C)C1=O</smiles>

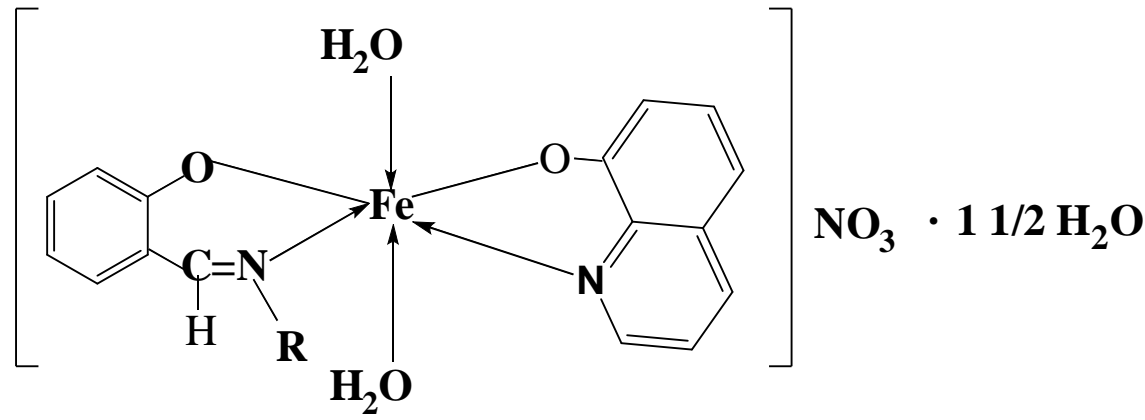<smiles>[R]=Nn1c(=O)c(C)c(C)n1C</smiles>

Fig.(1): Suggested structure of prepared complexes. 


\section{B - Bactericidal activity}

Preliminary screening experiments which are intended to detect the in vitro activity of the ligands and their metal complexes show the complexation of the ligands with some studies metals exhibit highlysignificant activity against gram-positive and other gram - negative, This result can be attributed to be expected synergic effect between the metal and ligand which depend on, the chelate effect of the ligands, the nature of donor atoms, nature of the metal and the oxidation state and the type of the counter ions that the neutralize thecomplex and the geometrical structure ofcomplexes [28].

Table (4)

Antibacterial activities of the ligands and their complexes showing inhibitionzone in diameters $(\mathrm{mm})$.

\begin{tabular}{|c||c||c|c||}
\hline \multirow{2}{*}{ Compounds } & \multicolumn{3}{|c||}{ Bacterial types } \\
\cline { 2 - 4 } & E.schriachia coli. & Staphlococcusarureus & Pseudomonasaerogenuosa \\
\hline \hline L & + & ++ & +++ \\
\hline \hline $\mathbf{L}^{-}$ & + & - & +++ \\
\hline \hline VL L & + & ++ & + \\
\hline CrL L & + & +++ & + \\
\hline \hline FeL L & + & +++ & + \\
\hline \hline CoL $\mathbf{L}^{-}$ & + & + & ++ \\
\hline \hline
\end{tabular}

$(-)$ : No significant Zone

$(+)$ : Inhibition Zone (4-10)

$(++)$ : Inhibition Zone (10-18)

$(+++)$ Inhibition Zone $(18-25)$

\section{Conclusion}

The ligands 2-hydroxybenzaldine-4aminoantipyrine and 8- hydroxyquinoline behaves as didentate ligand through $(\mathrm{N}, \mathrm{O})$ atoms. From the spectroscopy and analytical studies all complexes have Oh geometry except V (IV) complex have square pyramidal. From conductivity measurements showed the V(IV) and Co (II) complexes have nonionic nature while the $\mathrm{Cr}$ (III) and $\mathrm{Fe}$ (III) complexes have ionic nature and behaves as paramagnetism nature. The antibacterial activity of the complexes studies exhibit highly significant activity against gram. positive and other gram negative, this result can be attributed to be synergic effects.

\section{References}

[1] Alia S. K., Ibtisam J.D. and Manhel R.A., "Synthesis and Characterization of some Mixed Ligand Complexes Containing (8hydroxyquinoline) and (2-picoline) with some Metal Ions", J.B.for Sci., 10(2):369, 2013.

[2] Basma M., Rasmea M. and Huda A., "Synthesis and Characterization of some new metal complexes of eyhyl cyano(2methyl carboxylate phenyl azo acetate)"; Ibn Al-Haitham J. for Pure and Appl. Sci., 26(2), 178, 2014.

[3] Datt, N.K.; Chakder, N.C., "Complexes of cobalt (II) with some thiocarbazide derivatives", J.Inorg. Nucl. Chem. 33(2), 310, 2003. 
[4] Ydva, P.S. Devprakashand Senthikumar, G.P., "Benzothiazole: Different Methods of Synthesis and Diverse Biological Activities", Inter. J. of pharma. Sci. and Drug Res., 3(1), 01-07, 2011.

[5] Gupta, S. Ajmera, N. Gautam, N. Sharma, R.and Gauatam, D., Novel "Synthesis and biological activity study of pyrimido[2, 1-b] benzothiazoles", Ind.J. Chem., 48, 853-858, 2009.

[6] Rajeeva B., Srinivasulu N., and Shantakumar S.; "Synthesis and AntimicrobiAl activity of some new 2substituted benzothiazol derivatives", E-J. of Chem., 6(3), 775-779, 2009.

[7] Gaber M., Ayad M. M. and El-Sayed, V.S.; "Synthesis spectral and thermal Studies of $\mathrm{Co}(\mathrm{II}), \mathrm{Ni}(\mathrm{II})$, and $\mathrm{Cu}(\mathrm{II})$ complexes of 1(4, 6-dimethyl pyrimidine-2-ylazo)naphthalene-2-ol, Spectro", Chim. Acta A, 62(2), 694-702, 2005.

[8] Rafah F, Emad A. "Photochemical study of PVC filmes in presence of 2-[4-(2-methyl propyl) Phenyl] propanoate complexes, Arab J.Phys.Chem., 2(3), 68, 2015.

[9] Gup, R., Giziroglu, E .and Kirkan, B. "Synthesis and spectroscopic properties of newazodyes and azo-metal complexes derived from barbituricand amino quinoline, dyes pigments", 40(2), 40-46, 2007.

[10] a- Rageh, N. M. "Toutomeric structure, electronic spectra, acid -base properties of some 7-aryl -2, 5-diamino-3 (4-hydroxy phenyl azo) pyrazolo- [1, 5-a] pyrimidine 6- caronitrile) and effect of their $\mathrm{Cu}$ (II) complex solution on some bacteria and fungi"; 2004.

b- Emad Y. "Synthesis, spectroscopic studies and fungicidal activity of some diorganotin (IV) with 2-[(phenyl carbonyl) amino] propanoatpo", J. of King Saud University- Science, 24, 167-170, 2012.

[11] Chen- Shang, Yip-Foo Win, Sie-Tiong and Emad Yousif. "Synthesis, Characterization and Antibacterial Activity of Organotin (IV) Complexes Derivatives of 2- Chioro-4-nitrobenzoic Acid", Asian J. of Chem., 26(10), 2949-2953, 2014.

[12] Riordan O.A., Van Deun R., Mariraux E., Moynihon S., Fias P., Nochemam P., Binnemans K. and Redmond G. "Synthesis of a neodymium-quinolate Complex for near-infrared electrolum-inescence application", Thin solid Films, 616, 50985102, 2008.

[13] Gaber, M., El -Hefnaw, G., El- Borai M.A. And Mohamed N.F. "Synthesis spectral and thermal studies of $\mathrm{Mn}(\mathrm{II})$, $\mathrm{Co}(\mathrm{II}), \mathrm{Cu}(\mathrm{II})$ and $\mathrm{Zn}(\mathrm{II})$ Complex dyes based on hydroxyl quinoline moiety", J. Therm. Anal Calorim, 10, 1-9, 2011.

[14] Yousif, E. Adil H. and Farina, Y. "Synthesis and characterization of some Metal Ions with 22-amino Acetate Benzothiazol", J. Appl. Scie. Res., 6(7), 879- 882, 2010 .

[15] Petra D., Tatjano Z. and Boriset P. J. Inorg. Bio. Chemistry, 99 (2), 432-422, 2005.

[16] Nakamato, K. "Infrared and Raman Spectra of Inorganic and Coordination Compound", Jon Wiely and Sons L td $6^{\text {th }}$ Ed. 2009.

[17] Erdem, E., Sari, E. Y. Kilincarslan, R. and Kabay, N. 'Transition Metal Chemistery', 34, 167-174, 2009.

[18] Sanmartim J., Bermejo M. R., Garcia A. M. and Rivas I.M., J. Chem. Soc. Dalton Transition, 4174-4181, 2000.

[19] Socrates G. "Infrared Characteristic Group Frequencies"; Wiely, New York 1980.

[20] Kanagaraj G. and Rao G.N.; "Infrared and Raman Spectra of Inorganic and Coordination compounds", J. Basic and Applied Science, 4(10), 5178- 5183, 2010.

[21] Care F.A. "Organic Chemistery" $5^{\text {th }}$ ed., Graw - Hill, New York 2003.

[22] Shayma A., Shaker H.A., Mohammedana Abbas A.S, "Preparation Physico-Chemical and Spectroscopic Investigation of Thiaacetazone and Quinalizarin Complexes with $\mathrm{Mn}(\mathrm{II}), \mathrm{Fe}(\mathrm{II}), \mathrm{Co}(\mathrm{II}), \mathrm{Ni}(\mathrm{II}), \mathrm{Cu}(\mathrm{II})$ $\mathrm{Zn}$ (II) Cd(II) and Pd(II)", .J .of Basic and Applied Sciences, 4 (10), 5178-5183, 2010

[23] Fayad, N.K.AL Noor, T.H. and Ghanim, F.H. "Synthesis, characterization and antimicrobial activity of mixed ligand complexes of some metals with 1-nitroso-2naphthol and phenylalanine', Chem. Mater. Res., 2(5), 2012. 
[24] Nath, P. and Dhumwad, S.D. "Synthesis, characterization and antimicrobial studies of $\mathrm{Co}(\mathrm{II}), \quad \mathrm{Ni}$ (II), $\mathrm{Cu}$ (II) and $\mathrm{Zn}$ (II) complexes derived from a Schiff base of 2[(4-methyl-2-oxo -2-hchromen -7- yl] acetohydrazide with 3- formyl-2-hydroxy quinolone and 3-formyl-2mercaptoquinoline", J. Chem. pharm. Res., 4(1), 851-865, 2012.

[25] Jasim Z., U. "Synthesis, characterization of new $\mathrm{Mn}(\mathrm{II}), \mathrm{Co}(\mathrm{II}), \mathrm{Ni}(\mathrm{II})$ and $\mathrm{Cu}$ (II) complexes with [a-methyl-N-(3mrthylidene indol)-2- amino anthrquinone] ligand", Colle. Basic. Edu. Res. J., 10(4), 210-219, 2011

[26] Figgis, B. N. and Hitchman M. A. "Ligand Filed Theory and Its Application", Wiley New York .2000.

[27] Mishra A.P. and Jain R. "Microwave assisted synthesis, spectroscopic, thermal and antimicrobial studies of some transition metal complexes of Schiff base ligandscontaining thiazol moiety", Jord. J. Chem., 7(1), 9-21, 2012.

[28] Sultana N. and Arayne M.S.; "The use of conductivity measurements in organic solvent for the characterization of coordination compound", Pakistan J. Pharma Sci., 20(4), 305-310, 2007.

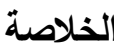

تم تحضير معقدات جديده بالطريقه التقليديه لليكاند

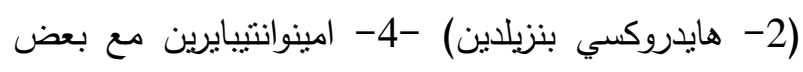

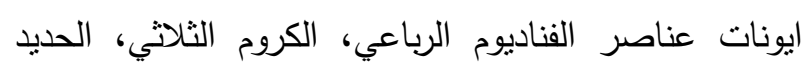

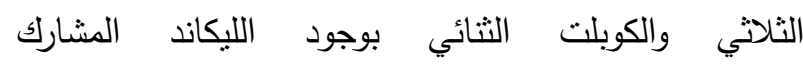
8- هايدروكسي كوينولين في وسط كحولي. شخصت المركبات المحضره بواسطة تقنيات الاثتعه تحت الحمراء والاشعه فوق البنفسجيه - المرئيه والحساسيه المغناطيسيه والامتصاص الذري اللهبي وكذلك التحليل الدقيق للعناصر والتوصيليه الكهربائيه. من خلال هذه الدراسات تم اقتراح الثكل الهندسي لمعقد الفناديوم هرم مربع القاعده والشكل هنداته ثماني السطوح لكل من المعقدات الكروم، الحديد والكوبلت.

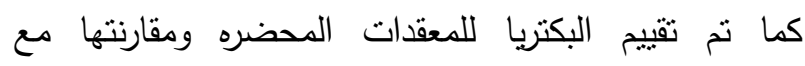

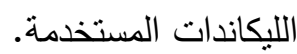

